\title{
Pecan Leaf Scorch in Response to Various Combinations of Nitrogen and Potassium Fertilization
}

\author{
Ray E. Worley \\ Department of Horticulture, University of Georgia Coastal Plain \\ Experiment Station, Tifton, GA 31793
}

Additional index words. Carya illinoensis, nutrient elements

Abstract. Nitrogen at 112 and $224 \mathrm{~kg} \cdot \mathrm{ha}^{-1}$ and $\mathrm{K}$ at $0,56,112,168$, and $224 \mathrm{~kg} \cdot \mathrm{ha}$ were applied to young 'Desirable' pecan [Carya illinoensis (Wangenh.) C. Koch] trees to evaluate their influence on leaf scorch. Scorch severity in the orchard decreased with time even though large imbalances of $\mathrm{N}$ and $\mathrm{K}$ existed. Scorch was increased only slightly by the high $\mathrm{N}$ and the zero $\mathrm{K}$ treatments. Little scorch was observed in trees receiving $\mathrm{K}$ applications. Increasing $\mathrm{K}$ rates $>56 \mathrm{~kg} \cdot \mathrm{ha}^{-1}$ did not reduce scorch. Correlation was not significant or very weak for leaf $\mathrm{N}$, leaf $\mathrm{K}$, or the leaf $\mathrm{N}: \mathrm{K}$ ratio with leaf scorch in the Ray City, Ga. study, depending on the year of observation. Another study at Tifton, Ga., revealed no correlation between scorch and leaf $\mathrm{K}$ or the leaf $\mathrm{N}: \mathrm{K}$ ratio. A very weak correlation occurred for scorch and leaf $\mathrm{N}$ in 1 of 2 years.

Pecan leaf scorch is a nebulous term used to describe several necrotic conditions of pecan leaves (Littrell et al., 1974; Sparks, 1988). The scorch discussed in this paper has been described as N-scorch (McGlohan, 1975; Ellis et al., 1984) after data of Sparks (1976b) indicated the condition was caused by an imbalance of $\mathrm{N}$ and $\mathrm{K}$. Pictures and a description of the malady are presented in those papers. N-scorch has been a serious problem for pecan growers, particularly those with young 'Desirable' trees. A high N : K application ratio was reported to induce the malady (Sparks, 1976b), but leaf N and K concentrations associated with the condition were not reported. Symptoms of N-scorch usually begin in June and end by the end of July, and should not be confused with cropinduced scorch that occurs on heavy cropproducing cultivars, such as 'Chickasaw', about the time of shuck dehiscence. Potassium deficiency and, more recently, $\mathrm{P}$ deficiency have been implicated in the cropinduced scorch (Sparks, 1988). Many growers were reporting damage from the $\mathrm{N}$-scorch syndrome when trees received liberal applications of K. Severe leaf scorch was observed in a young 'Desirable' orchard in Ray City, Ga., after a grower used an estimated $0.45 \mathrm{~kg} /$ tree per year rate of $5 \mathrm{~N}-4.4 \mathrm{P}-12.5 \mathrm{~K}$. Since the fertilizer was high in $\mathrm{K}$, the N/K imbalance theory was inappropriate. The orchard was selected to further study the relationship between leaf scorch and $\mathrm{N}$ and $\mathrm{K}$ applications and their relationship with leaf $\mathrm{N}$ and $\mathrm{K}$ and the $\mathrm{N}: \mathrm{K}$ ratio. Another or-

Received for publication 13 Apr. 1989. I acknowledge Ben Mullinex, statistical consultant, for assistance with the statistical analysis and Brenda Bishop for typing the manuscript. The cost of publishing this paper was defrayed in part by the payment of page charges. Under postal regulations, this paper therefore must be hereby marked $a d$ vertisement solely to indicate this fact. chard at Tifton, Ga., had similar scorch on a young 'Shoshoni' pecan planting. Data were collected from this orchard to determine if leaf scorch severity was associated with leaf nutrient concentrations and the leaf $\mathrm{N}: \mathrm{K}$ ratio.

The study at Ray City (southern Georgia) was conducted on Fuqua loamy sand (Plinthic Paleudult, loamy, siliceous, thermic, arenic) that had been in native woodland. 'Desirable' trees, spaced $15 \times 15 \mathrm{~m}$, were 5 years old at the beginning of the study. Nitrogen application rates were 112 and $224 \mathrm{~kg} \cdot \mathrm{ha}^{-1}$ in factorial combination with $\mathrm{K}$ at 0,56 , 112 , and $168 \mathrm{~kg} \cdot \mathrm{ha}^{-1}$. In addition, $224 \mathrm{~kg}$ $\mathrm{K} /$ ha were used with the high $\mathrm{N}$ rate only. The $\mathrm{N}$ source was $\mathrm{NH}_{4} \mathrm{NO}_{3}$ and the $\mathrm{K}$ was from $\mathrm{KCl}$, except in 1984 when Sul-Po-Mag $(18 \% \mathrm{~K}, 22 \% \mathrm{~S}$, and $11 \% \mathrm{Mg}$; IMC Fertilizer, Mundelein, Ill. ) was used. All treatment combinations were replicated four times in a randomized complete-block design, giving a total of 16 replications of the low $\mathrm{N}$ and 20 replications of the high $\mathrm{N}$ treatment. The highest $\mathrm{K}$ treatment was replicated four times and the others were replicated eight times within each year. Single-tree plots were used without borders since trees were small and relatively widely spaced. Fertilizer was year for 11 years. The area fertilized was within the following radii of the trunk: $3 \mathrm{~m}$ in 1976-78, $4 \mathrm{~m}$ in 1979 and $1980,5 \mathrm{~m}$ in $1981,6 \mathrm{~m}$ in 1982 ; the total $15 \times 15-\mathrm{m}$ square was fertilized in 1983-86. The treatthe application and not to the total area in the orchard allotted to a tree, except for the last 4 years when the total area was covered. Leaf scorch severity was rated by visually observing each tree and giving it a rating on a 0 to 9 scale $(0=$ no scorch, $5=$ about half the leaflets showing scorch, and $9=$ practically all leaflets scorched) in 1976 and 1977. Thereafter a more objective scale was applied by hand in February or March each ment rates refer to the area actually receiving used. The number of scorched leaflets per leaf or those missing due to scorch were counted on 50 compound leaves from each tree (12 to 13 adjacent leaves on each of four sides) in June or July of each year. Commercial insect and disease control was used and trees were drip-irrigated.

Leaf samples were collected by taking 50 middle leaflets from middle leaves on terminals in the area of maximum limbspread (about two-thirds the distance from the ground to the tree top) in July. Leaves appeared to be clean and were not washed. They were dried in a forced-air oven and ground to pass a 20-mesh sieve. Analysis used standard procedures (Jones and Warner, 1969; Warner and Jones, 1970) through 1978. Thereafter, leaf $\mathrm{N}$ was determined by the AOAC macro-Kjeldahl procedure (Horwitz, 1980) and $\mathrm{K}, \mathrm{Ca}, \mathrm{Mg}, \mathrm{Fe}, \mathrm{Mn}$, and $\mathrm{Zn}$ were determined by atomic absorption and $\mathrm{P}$ was determined calorimetrically by developing a yellow vanadomolybdophosphoric-acid color from an ash extract. Data were analyzed using the General Linear Models analysis of variance and correlation procedures of SAS (SAS Institute, Inc., 1982). Since treatments were continuous variables, the linear and quadratic regression components are presented in tables. Non regression models were also computed, but are not presented in tables. The $\mathrm{N}$ and $\mathrm{K}$ interaction component was also calculated. A correlation matrix calculated each year and for all years combined included leaf scorch rating or leaf scorch count with yield; leaf $\mathrm{N}, \mathrm{P}, \mathrm{K}, \mathrm{Ca}, \mathrm{Mg}, \mathrm{Fe}, \mathrm{Mn}$, $\mathrm{Zn}, \mathrm{N}$ : K ratio; and soil $\mathrm{pH}, \mathrm{P}, \mathrm{K}, \mathrm{Ca}$, and $\mathrm{Mg}$.

At Tifton (southern Georgia), a local pecan grower's orchard had moderate to severe scorch even though recommended fertilization practices had been followed. In this orchard, we related leaf mineral nutrition to the intensity of scorch. Leaf samples were collected and counts of the number of scorched or missing leaflets per 50 leaves were made, as described in the Ray City study, on 107 young 'Shoshoni' trees with varying amounts of scorch in 1978 and 1979. The soil was a Tifton loamy sand (Ultisol Plinthic Paleudults, fine loamy siliceous, thermic). Correlation coefficients ( $r$ values) were calculated for leaf scorch counts with leaf $\mathrm{N}, \mathrm{P}, \mathrm{K}, \mathrm{Ca}$, $\mathrm{Mg}, \mathrm{Fe}, \mathrm{Mn}$, and $\mathrm{Zn}$.

Although leaf scorch in the Ray City orchard was severe before treatments began, it decreased as the study progressed, and only a low incidence of scorch was present in later years (Table 1). Less than one leaflet per leaf was scorched during the last 3 years of the study for the most severely affected treatment. Scorch rating or number of scorched leaflets per leaf was slightly greater for the high $\mathrm{N}$ than for the low $\mathrm{N}$ treatment in 1977 , 1981, 1983, and the overall average, but differences were of no practical significance. The average leaf $\mathrm{N}$ concentration ranged from $2.28 \%$ for the low $\mathrm{N}$ application rate in 1977 to $2.72 \%$ for the high $\mathrm{N}$ application rate in 1985. The leaf $\mathrm{K}$ concentration ranged from $0.48 \%$ for the 0 -rate of $\mathrm{K}$ application in 1986 to $1.28 \%$ for the $168-\mathrm{kg} \cdot \mathrm{ha}^{-1}$ rate in 1982 . 
Table 1. Pecan leaf scorch rating or number of scorched leaflets or those missing due to scorch (1978-86) as affected by $\mathrm{N}$ and $\mathrm{K}$ applications (197677), Ray City, Ga.

\begin{tabular}{|c|c|c|c|c|c|c|c|c|c|c|c|c|}
\hline \multirow{3}{*}{$\begin{array}{l}\text { Fertilizer } \\
\left(\mathrm{kg}^{\prime} \mathrm{ha}^{-1}\right)\end{array}$} & \multicolumn{11}{|c|}{ Year of evaluation } & \multirow{3}{*}{$\begin{array}{l}\text { 9-Year } \\
\text { average }\end{array}$} \\
\hline & $\underline{1976}$ & 1977 & $\underline{1978}$ & 1979 & 1980 & 1981 & 1982 & 1983 & 1984 & 1985 & 1986 & \\
\hline & \multicolumn{2}{|c|}{ Scorch rating ${ }^{2}$} & \multicolumn{9}{|c|}{ Scorched or missing leaflets (no.) } & \\
\hline \multicolumn{13}{|l|}{ Nitrogen } \\
\hline 112 & 1.31 & 2.15 & $1.01^{\prime}$ & 0.76 & 0.62 & 0.98 & 0.69 & 1.09 & 0.38 & 0.18 & 0.15 & 0.64 \\
\hline 224 & 1.80 & 4.34 & 1.39 & 1.19 & 0.78 & 1.88 & 1.27 & 2.23 & 0.33 & 0.30 & 0.32 & 1.07 \\
\hline \multicolumn{13}{|l|}{ Potassium } \\
\hline 0 & 1.13 & 2.30 & 1.55 & 0.61 & 0.63 & 1.77 & 1.28 & 2.61 & 0.86 & 0.84 & 0.69 & 1.18 \\
\hline 56 & 1.50 & 4.38 & 0.84 & 1.46 & 0.83 & 1.41 & 1.11 & 1.85 & 0.25 & 0.08 & 0.14 & 0.88 \\
\hline 112 & 1.25 & 3.18 & 1.24 & 0.63 & 0.49 & 1.06 & 0.84 & 1.13 & 0.20 & 0.06 & 0.08 & 0.69 \\
\hline 168 & 1.75 & 3.00 & 1.39 & 0.79 & 1.04 & 1.54 & 0.88 & 1.13 & 0.19 & 0.08 & 0.14 & 0.79 \\
\hline 224 & 2.00 & 4.50 & 1.13 & 1.45 & 0.58 & 1.60 & 0.70 & 2.08 & 0.15 & 0.10 & 0.10 & 0.88 \\
\hline \multicolumn{13}{|l|}{ Contrasts } \\
\hline $\mathrm{N}$ linear & NS & $*$ & NS & NS & NS & ** & NS & * & NS & NS & NS & $* *$ \\
\hline $\mathbf{K}$ linear & NS & NS & NS & NS & NS & NS & NS & NS & * & ** & $* *$ & $* *$ \\
\hline $\mathbf{K}$ quadratic & NS & NS & NS & NS & NS & NS & NS & NS & NS & ** & NS & NS \\
\hline $\mathrm{K}$ cubic & NS & NS & NS & NS & NS & NS & NS & NS & NS & NS & NS & NS \\
\hline Interactions & NS & NS & NS & NS & NS & NS & NS & NS & NS & NS & NS. & NS \\
\hline
\end{tabular}

${ }^{z}$ Scorch rating was $0=$ no scorched leaflets and $9=$ practically all leaflets scorched.

Ns,****Nonsignificant at $P=0.05$ or significant at $P=0.05$ or 0.01 , respectively.

In $1976-83, \mathrm{~K}$ rate did not affect the amount of scorch. Increasing the $\mathrm{K}$ application rate decreased the number of scorched leaves slightly during the last 3 years of the study and for the overall average. $t$ Tests among $\mathrm{K}$ rates indicated the difference to be between the $0 \mathrm{~K}$ rate and the other rates. There were no differences in the amount of leaf scorch between treatments receiving $\mathrm{K}$ applications. The $\mathrm{N}$ rate $\times \mathrm{K}$ rate interaction for leaf scorch was not significant in any year or for all years combined. The linear correlation coefficient $(r)$ for leaf scorch count with leaf $\mathrm{N}$, leaf $\mathrm{K}$, and the leaf $\mathrm{N}: \mathrm{K}$ ratio for all years combined was $0.005,0.072$, and -0.009 , respectively. None of these were significant, and their closeness to 0 indicates essentially no relationship. Individual year correlation coefficients for leaf $\mathrm{K}$ and scorch count were significant for 4 of 9 years and ranged from +0.35 to -0.59 . Leaf $\mathrm{N}$ and leaf scorch count correlation coefficients were significant in 4 years and ranged from -0.35 to +0.57 . The leaf $\mathrm{N}: \mathrm{K}$ ratio and leaf scorch count correlation coefficient was significant only in the last year $(r=0.67)$. Scorch count was not correlated with yield in any year.

Leaf scorch counts at the orchard in Tifton ranged from 0.02 to 9.50 scorched leaflets per leaf during the 2 years. The correlation coefficients for scorch count with leaf $\mathrm{N}, \mathrm{K}$, and the $\mathrm{N}: \mathrm{K}$ ratio were $0.11,0.10$, and 0.005 , respectively, in 1978 and $0.26,0.12$, and 0.003 in 1979 . Only the correlation coefficient of 0.26 for leaf $\mathrm{N}$ was significant at the $95 \%$ level of probability and thus would account for only $7 \%$ of the variation in leaf scorch. The largest correlation coefficient for any criterion with leaf scorch was -0.47 for leaf $\mathrm{P}$ concentration in 1979.
If the leaf scorch syndrome were caused by excessive $\mathrm{N}$ in relation to $\mathrm{K}$, then it would be expected to increase at high application rates of $\mathrm{N}$ and to decrease with increasing application of $\mathrm{K}$. The orchards used to study the scorch syndrome were seriously affected by leaf scorch, at least initially. Large imbalances of $\mathrm{N}$ and $\mathrm{K}$ were induced at Ray City, but the scorch condition became less severe instead of increasing. By the end of the study, less than one leaflet per leaf was scorched in the most severely affected treatment. The increase in scorch from doubling the $\mathrm{N}$ rate was small and of no practical significance; thus, there is no evidence from this study that $\mathrm{N}$ rates of $224 \mathrm{~kg} \cdot \mathrm{ha}^{-1}$ or less would cause a scorch problem. Pecans can withstand high salts from massive rates of $P$ and K, as shown by Sparks (1988) while studying crop-induced scorch-an entirely different type of leaf scorch. There was little indication that increasing rates of $\mathrm{K}$ reduced leaf scorch, until the last 3 years when leaf $\mathrm{K}$ concentrations were $<0.60 \%$, In these years, practically all the scorch was in trees receiving no $\mathrm{K}$, thus suggesting that scorch might be an indicator of beginning stages of K deficiency, as stated by Sparks (1976a).

If scorch is caused by an imbalance of $\mathrm{N}$ and $\mathrm{K}$, then a significant $\mathrm{N}$ rate $\times \mathrm{K}$ rate interaction would be expected. It would take more $\mathrm{K}$ to prevent leaf scorch at the higher $\mathrm{N}$ rate. There was never a significant $\mathrm{N} \times$ $\mathrm{K}$ interaction in any year or in combined years to support the $\mathrm{N} \times \mathrm{K}$ imbalance theory.

If scorch is caused by an imbalance of $\mathrm{N}$ and $\mathrm{K}$, then leaf $\mathrm{N}$ would be positively correlated with leaf scorch intensity and leaf $\mathrm{K}$ would be negatively correlated with leaf scorch intensity. Also the leaf $\mathrm{N}: \mathrm{K}$ ratio would be positively correlated with leaf scorch intensity. None of these correlations from the Ray City study supported the N/K imbalance theory. The orchard at Tifton, in contrast, had a substantial and varied amount of scorch, but still there was no correlation between scorch and leaf $\mathrm{K}$ or the leaf $\mathrm{N}$ : K ratio, and the correlation between scorch and leaf $\mathrm{N}$ was very weak.

The data from these tests and observations of abundant scorch on growers' orchards that have been well fertilized with $\mathrm{K}$ indicate that the N-scorch syndrome is caused by something other than an $\mathrm{N} / \mathrm{K}$ imbalance.

\section{Literature Cited}

Ellis, H.C., P.F. Bertrand, and T.F. Crocker. 1984. Pecan pest management in the southeast. Ga. Coop. Ext. Ser. MP176.

Horwitz, W. (ed.). 1980. Official methods of analysis of the Assn. Agr. Chemists. 13th ed. Assn. Offic. Agr. Chemists. Washington, D.C. p. 15 , sec. 2.058 .

Jones, J.B. and M.H. Warner. 1969. Analysis of plant ash solutions by spark emission spectroscopy. Dev. Appl. Spectros. 7A:152-160.

Littrell, R.H., R.E. Worley, and J.A. Payne. 1974. Fungal leaf scorch of pecan. Proc. Southeastern Pecan Growers Assn. 67:143-146.

McGlohan, N.E. 1975. Pecan leaf diseases. Pecan South 2(2):36-38.

SAS Institute, Inc. 1982. SAS user's guide: Statistics. SAS Inst., Cary, N.C.

Sparks, D. 1976a. Some nutrient deficiency symptoms of pecan. Pecan South 3(1):264-267.

Sparks, D. 1976b. Nitrogen scorch and the pecan. Pecan South 3(5):500-501

Sparks, D. 1988. Growth and nutrition of pecan in response to phosphorus. J. Amer. Soc. Hort. Sci. 113:850-859.

Warner, M.H. and J.B. Jones. 1970. A rapid method for nitrogen determination in plant tissue. Soil Sci. \& Plant Anal. 1:109-114. 